\title{
Comparison of Color Change to pH Range and Acid-Base Titration Indicator Precision Test of Multiple Ethanol Extracts
}

\author{
Lilis Tuslinah ${ }^{1}$, Anna Yuliana ${ }^{1}$, Dian Arisnawati ${ }^{1}$ and Lina Rahmawati Rizkuloh ${ }^{2, *}$ \\ ${ }^{1}$ Department of Pharmacy, Bakti Tunas Husada Institute of Health Science, Tasikmalaya, \\ West Java 46115, Indonesia \\ ${ }^{2}$ Department of Pharmacy, Perjuangan University, Tasikmalaya, West Java 46115, Indonesia
}

(*Corresponding author's e-mail: lina@unper.ac.id)

Received: 19 August 2020, Revised: 14 May 2021, Accepted: 14 June 2021

\begin{abstract}
Natural indicators using anthocyanin compounds can be an alternative to synthetic indicators on acid-base titration because anthocyanin is an organic compound that is unstable with changes in $\mathrm{pH}$. The extraction was carried out with ethanol because the compounds of anthocyanin were polar. This study was to ensure an ethanol extract of some plants could be used as an acid-base indicator that had a $\mathrm{pH}$ range of color change and the value of the equality parameter was not significantly different from the phenolphthalein indicator. The research method is to collect research journals on making natural indicators from ethanol extracts of various plants compared to phenolphthalein indicators so that secondary data from these journals can be processed statistically. Research results and conclusions: Based on the results of statistical data processing using the t-test there was no difference in the average $\mathrm{pH}$ of the phenolphthalein indicator with the average $\mathrm{pH}$ of ethanol extracts of adam air leaves (Rheo discolor), white frangipani flowers and Clitoria teratea L., with a significance value $>0.05$ and the equality test (precision) had the requirements of good equality.
\end{abstract}

Keywords: Anthocyanin, Indicator of acid-base Titration, Ethanol, Precision

\section{Introduction}

Indicators are chemicals that are sensitive enough to display very close color changes in the titration process where equal amounts of analytes and titrants react with each other [1]. The acid-base indicator is a substance that can produce color changes according to the $\mathrm{pH}$ of the solution so that it can be known the acidic and basic properties of the solution [2] cause color changes and can be used to predict acidic $\mathrm{pH}$ and basic $\mathrm{pH}$ [3] has a special color at a certain $\mathrm{pH}$ as well as showing changes in $\mathrm{pH}$ at the time of titration [4].

Anthocyanins dyes are appropriate as indicators because anthocyanins are organic compounds that are unstable with changes in $\mathrm{pH}$. In $\mathrm{pH} 1-2$ is a stable condition of anthocyanin which is in the form of a colored cavity flavilium, when the $\mathrm{pH}$ is increased anthocyanins becomes colorless due to changes in $\mathrm{pH}$ [5]. In making, this natural indicators the extraction process will affect the withdrawal of the compound, where the selection of the solvent also plays an important role because it determines the success or failure of the extraction process [6]. Because anthocyanin compounds are polar, extraction is carried out using polar solvents such as ethanol [7].

The aim of this research is to ensure an ethanol extract of some plants can be used as an indicator of the acid-base that has a $\mathrm{pH}$ range of color changes and the value of the equality parameter is not significantly different from the phenolphthalein indicator.

\section{Materials and methods}

Collecting research journals on making natural indicators from ethanol extracts of various plants compared to phenolphthalein indicators so that secondary data from these journals can be processed statistically. 


\section{Results and discussion}

Utilization of natural materials

According to Yulfriansyah and Novitriani [8], indicators by utilizing anthocyanin compounds in natural materials because they have color characteristics so that at each $\mathrm{pH}$ will display and provide different color changes.

Table 1 Natural Ingredients as a Natural Indicator.

\begin{tabular}{cll}
\hline No. & \multicolumn{1}{c}{ Natural Ingredients } & \multicolumn{1}{c}{ Information } \\
\hline 1. & Adam's Eve Leaves & $\begin{array}{l}\text { Potential study of Adam's Eve Leaf extract (Rheo discolor) as } \\
\text { indicator of acid-base titration [9] }\end{array}$ \\
2. & $\begin{array}{l}\text { Red Cambodian Flower and } \\
\text { Extraction and utilization of natural products (Pulmeria species) } \\
\text { grown in Ankpa, Kogi state, Nigeria: An environmentally friendly } \\
\text { source of acid-base indicator for titrimetric analysis [10] }\end{array}$ \\
Butterfly pea (Clitoria Ternate L.) extract as indicator of acid - \\
base titration [11]
\end{tabular}

\section{Effect of solvents}

According to Ginanjar et al. [14] that in the extraction process there is a withdrawal of the compound from the active ingredient by the solvent used by the nature of polarity between the compound and the solvent. Anthocyanin is a polar compound, so to extract anthocyanin compounds, polar solvents are needed, one of which is by using ethanol as a solvent. Explained by Delazar et al. [15] that ethanol, methanol and acetone are the types of solvents that often used to extract phenolic compounds in plants and herbal plants

In a study conducted by Amin and Yuliana [16], natural dyes are very sensitive to changes in physics and chemistry one of the factors is the use of high temperatures because it can cause damage to these natural dyes. Therefore, the choice of ethanol as a solvent is due to anthocyanin which is polar, the solvent is also volatile so that when processing and concentrating does not require too high a temperature, this is to minimize damage to anthocyanin compounds that are not stable to high temperatures. Ethanol is a type of solvent that can attract polar and non-polar compounds [17], due to the presence of OH groups in ethanol so that it can dissolve polar molecules and the presence of alkyl groups, namely $\mathrm{CH}_{3} \mathrm{CH}_{2}$ which can bind non-polar molecules.

\section{Statistical data analysis of acid-base titration and indicators of natural ingredients}

In research conducted by Nining et al. [18], it is explained that the color changes that occur from the use of these indicators because they are influenced by the stability of anthocyanin compounds, where one of the factors that influence the stability of anthocyanin compounds is the $\mathrm{pH}$ condition.

Statistical data analysis was performed on the results of a titration between strong acids, $0.1 \mathrm{~N} \mathrm{HCl}$, and a strong base, $0.1 \mathrm{~N} \mathrm{NaOH}$ with phenolphthalein indicator and ethanol extract indicators of various plants. Statistical analysis was performed on the final $\mathrm{pH}$ achieved between the 2 indicators in reaching the endpoint of the titration. The results of the data analysis showed that between the 2 data there were no significant differences. The results can be seen from the sig- 2 tailed value of $>0.05$ between the phenolphthalein indicator and ethanol extracts of Adam's Eve Leaves with a pH range of 8.97 - 10.2 with color changes produced from reddish-orange to brownish green; ethanol extract of white Cambodian flowers with a $\mathrm{pH}$ range of 12.55 - 12.56 with color changes from initially colorless to gold; and ethanol extracts of telang flowers with a $\mathrm{pH}$ range of 12.67 - 12.69. Data can be seen in the following table: 
Table 2 Final $\mathrm{pH}$ data in reaching the end point of acid base titration between phenolphthalein indicator and ethanol extract indicator of various plants.

\begin{tabular}{|c|c|c|c|c|c|c|}
\hline $\begin{array}{l}\text { Indicator } \\
\text { name }\end{array}$ & Repeat & $\begin{array}{c}\text { Final } \\
\text { pH }\end{array}$ & $\underset{\text { (2-tailed) }}{\text { Sig }}$ & $\begin{array}{c}\text { Indicator name } \\
\text { for natural } \\
\text { materials }\end{array}$ & $\begin{array}{c}\text { Final } \\
\text { pH }\end{array}$ & $\underset{\text { (2-tailed) }}{\text { Sig }}$ \\
\hline \multirow{4}{*}{ Phenolphthalein } & 1 & 9.3 & \multirow{4}{*}{0.351} & \multirow{4}{*}{ Adam's Eve Leaves } & 9.99 & \multirow{4}{*}{0.400} \\
\hline & 2 & 9.25 & & & 10.2 & \\
\hline & 3 & 9.4 & & & 8.97 & \\
\hline & Average & 9.32 & & & 9.72 & \\
\hline \multirow{4}{*}{ Phenolphthalein } & 1 & 12.56 & \multirow{4}{*}{0.099} & \multirow{4}{*}{$\begin{array}{l}\text { White Cambodian } \\
\text { Flower }\end{array}$} & 12.55 & \multirow{4}{*}{0.099} \\
\hline & 2 & 12.57 & & & 12.56 & \\
\hline & 3 & 12.57 & & & 12.56 & \\
\hline & Average & 12.56 & & & 12.56 & \\
\hline \multirow{4}{*}{ Phenolphthalein } & 1 & 12.67 & \multirow{4}{*}{0.197} & \multirow{4}{*}{ Telang Flower } & 12.67 & \multirow{4}{*}{0.197} \\
\hline & 2 & 12.66 & & & 12.69 & \\
\hline & 3 & 12.67 & & & 12.67 & \\
\hline & Average & 12.67 & & & 12.67 & \\
\hline
\end{tabular}

Changing $\mathrm{pH}$ conditions will cause changes in the structure of anthocyanin compounds and cause changes in color in the solution. In a study conducted by [19], it was explained that the stability of the anthocyanin structure can cause the hydrolysis compounds to undergo hydrolysis, that is the glycosidic bonds and the aglycotic ring become exposed, resulting in the formation of various unstable aglycones, which in the next stage produces carbinol and chalcone groups which are colorless. A following figure is a form of anthocyanin imbalance due to changes in $\mathrm{pH}$.

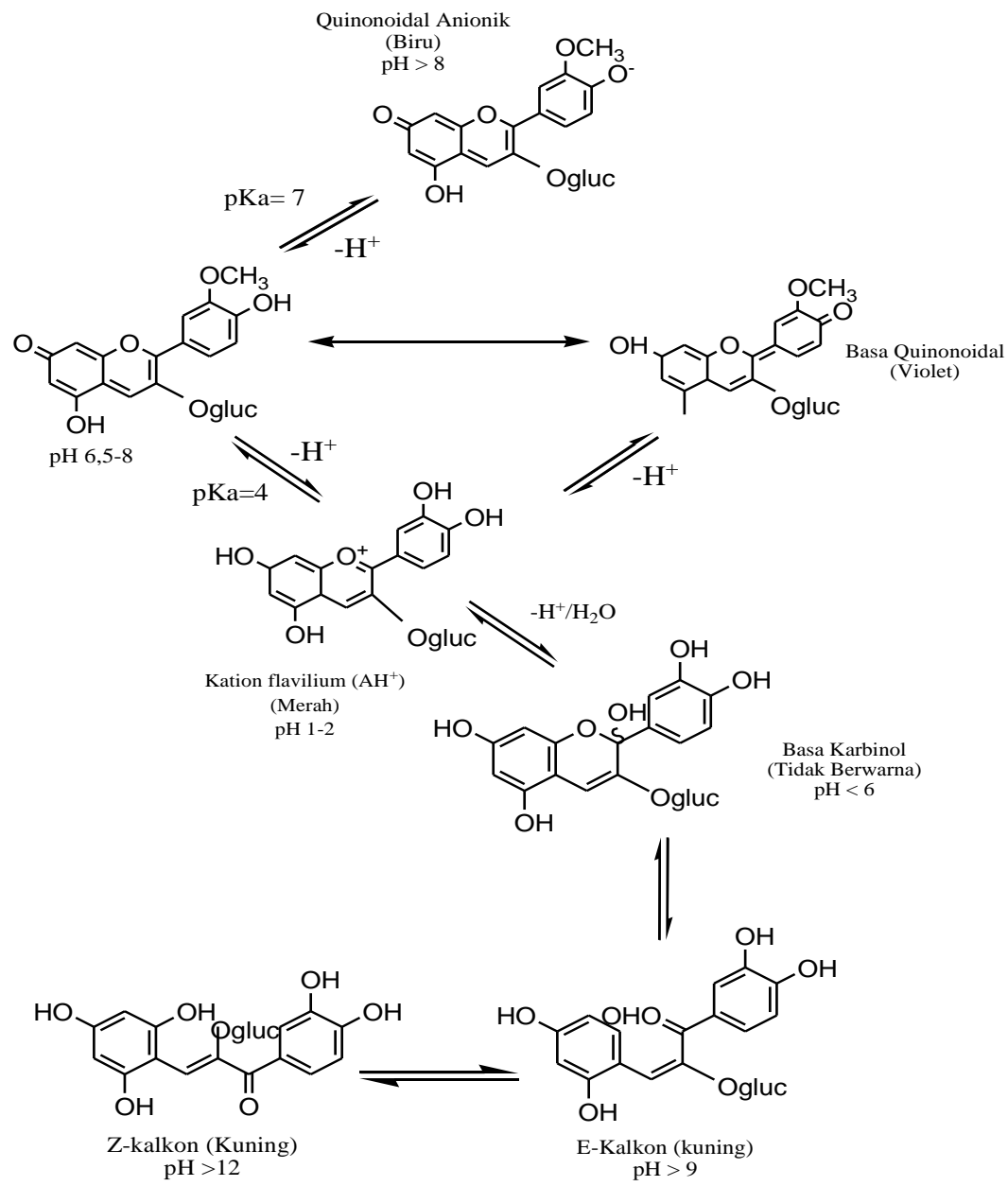

Figure 1 Form of anthocyanin balance due to changes in $\mathrm{pH}[13]$. 


\section{Equality test}

This equality test is carried out to determine the suitability of the results of the tests carried out in the same concentration. Equality test can be measured from the value of the resulting standard deviation or relative standard deviation (coefficient of variation), because equality (precision) is a standard deviation or Relative Standard Deviation (\% RSD) which is a criterion in this test with acceptable limits. The following are the results of the equality test.

Table 3 Equivalence test uses various indicators of ethanol extract of plants.

\begin{tabular}{|c|c|c|c|c|c|c|}
\hline $\begin{array}{l}\text { Plant extract } \\
\text { name }\end{array}$ & Repeat & $\begin{array}{c}\mathbf{H C l} \\
\text { concentration } \\
(\mathbf{N}) \\
\end{array}$ & $\begin{array}{c}\text { Calculate } \mathrm{HCl} \\
\text { concentration } \\
(\mathrm{N})\end{array}$ & $\begin{array}{c}\text { Recovery } \\
(\%)\end{array}$ & SD & $\begin{array}{r}\text { RSD } \\
(\%)\end{array}$ \\
\hline \multirow{4}{*}{$\begin{array}{l}\text { Adam's Eve } \\
\text { Leaves }\end{array}$} & 1 & 0.1 & 0.11 & 112 & \multirow{4}{*}{$1 \times 10^{-4}$} & \multirow{4}{*}{0.09} \\
\hline & 2 & 0.1 & 0.11 & 117 & & \\
\hline & 3 & 0.1 & 0.11 & 111 & & \\
\hline & Average & 0.1 & 0.11 & 113.33 & & \\
\hline \multirow{4}{*}{$\begin{array}{l}\text { Red Cambodian } \\
\text { Flower }\end{array}$} & 1 & 0.1 & 0.07 & 72 & \multirow{4}{*}{$39 \times 10^{-4}$} & \multirow{4}{*}{0.54} \\
\hline & 2 & 0.1 & 0.07 & 72 & & \\
\hline & 3 & 0.1 & 0.07 & 72 & & \\
\hline & Average & 0.1 & 0.07 & 72 & & \\
\hline \multirow{4}{*}{$\begin{array}{l}\text { White } \\
\text { Cambodian } \\
\text { Flower }\end{array}$} & 1 & 0.1 & 0.06 & 58 & \multirow{4}{*}{$8 \times 10^{-4}$} & \multirow{4}{*}{1.33} \\
\hline & 2 & 0.1 & 0.06 & 58 & & \\
\hline & 3 & 0.1 & 0.06 & 58 & & \\
\hline & Average & 0.1 & 0.06 & 58 & & \\
\hline \multirow{4}{*}{$\begin{array}{l}\text { Butterfly Pea } \\
\text { Flower }\end{array}$} & 1 & 0.1 & 0.10 & 98 & \multirow{4}{*}{$26 \times 10^{-7}$} & \multirow{4}{*}{0.003} \\
\hline & 2 & 0.1 & 0.10 & 97 & & \\
\hline & 3 & 0.1 & 0.10 & 98 & & \\
\hline & Average & 0.1 & 0.10 & 97.66 & & \\
\hline \multirow{4}{*}{$\begin{array}{c}\text { Black Sticky } \\
\text { Rice }\end{array}$} & 1 & 0.1 & 0.10 & 105.2 & \multirow{4}{*}{$5 \times 10^{-5}$} & \multirow{4}{*}{0.05} \\
\hline & 2 & 0.1 & 0.10 & 105.3 & & \\
\hline & 3 & 0.1 & 0.10 & 105.2 & & \\
\hline & Average & 0.1 & 0.10 & 105.3 & & \\
\hline \multirow{4}{*}{ Telang Flower } & 1 & 0.1 & 0.09 & 87 & \multirow{4}{*}{$5 \times 10^{-5}$} & \multirow{4}{*}{0.06} \\
\hline & 2 & 0.1 & 0.10 & 97 & & \\
\hline & 3 & 0.1 & 0.09 & 89 & & \\
\hline & Average & 0.1 & 0.09 & 91 & & \\
\hline
\end{tabular}

In the table above can be seen from the SD or standard deviation where for all the data from the ethanol extracts of the various plants show the distribution of data close to each other, and also seen in the $\% \mathrm{RSD}$ value, the result is $\leq 1 \%$ for Adam leaf extract air, red Cambodia flowers, butterfly pea flower, black sticky rice and telang flowers that show the data have a very thorough accuracy, and meticulous for white Cambodia flowers with $\%$ RSD $\leq 2 \%$, so that the data can be said to meet the parameters of good equality. 


\section{Conclusions}

Based on statistical data processing from this study there was no significant difference between the average $\mathrm{pH}$ of the phenolphthalein indicator and the average $\mathrm{pH}$ of the ethanol extract of Adam's Eve Leaves, ethanol extracts of white Cambodia flowers and ethanol extracts of telang flowers in producing color changes, and in the test the similarity of SD shows the distribution close to each other and the value of $\% \mathrm{RSD} \leq 1 \%$ for extracts of Adam's Eve Leaves, red cambodia flowers, butterfly pea flower, black sticky rice and telang flowers and white cambodia flowers with $\% \mathrm{RSD} \leq 2 \%$, so that the data can be said to meet the parameters of good equality.

\section{References}

[1] K Ashutosh. Pharmaceutical drug analysis. $3^{\text {rd }}$ eds. New Age International Publishers Ltd., New Delhi-India, 2005, p. 688.

[2] R Riniati, A Sularasa, and AD Febrianto. Hibiscus (Hibiscus rosa sinensis) extraction using methanol solvents with the soxhletation method for acid base titration indicators. Indones. J. Chem. Anal. 2019; 2, 34-40.

[3] F Frantauansyah, S Nuryanti and B Hamzah. Extract of Hibiscus tiliaceus as an acid-base indicator. J. Acad. Chem. 2013; 2, 11-16.

[4] DA Virliantari, A Maharani and U Lestari. Manufacture of acid-base natural indicators from red onion peel extract (Alliumascalonicum L.). In: Proceedings of the National Seminar on Science and Technology, Universitas Muhammadiyah Jakarta, Jakarta, Indonesia. 2018, p. 1-6.

[5] F Pina. Chemical applications of anthocyanins and related compounds. A source of bioinspiration. J. Agric. Food Chem. 2014; 62, 6885-97.

[6] IO Angelia. Variation of solvent concentration in the anthocyanin extraction process of purple sweet potatoes. J. Agric. Technol. Sci. 2019; 3, 16-26.

[7] LA Wicaksono, S Winarti and D Amalusholikha. Effect of various proportions of solvents on extraction and stability of mangosteen fruit natural dyes Phyllantus reticulatus. J. Food Technol. Ind. 2019; 4, 27-35.

[8] A Yulfriansyah and K Novitriani. Making indicators of natural ingredients from dragon fruit hylocereuspolyrhizus skin extract as alternative indicators of acid bases based on soaking time variations. Bakti Tunas Husada. J. Sci. Nurs. Sci. Health Anal. Pharm. 2016; 16, 153.

[9] S Ratnasari, D Suhendar and V Amalia. Potential study of Adam's Eve Leaf extract (Rheo discolor) as indicator of acid-base titration. J. Chimica et Natura Acta. 2016; 4, 39-46.

[10] LO Abuh, SA Egu and AA Isah. Extraction and utilization of natural products (Pulmeria species) grown in Ankpa, Kogi state, Nigeria: An environmentally friendly source of acid-base indicator for titrimetric analysis. J. Basic Appl. Res. Int. 2016; 18, 49-52.

[11] B Wiyantoko and A Astuti. Butterfly pea (Clitoria Ternate L.) extract as indicator of acid-base titration. Indones. J. Chem. Anal. 2020; 3, 22-32.

[12] MA Hasibuan, EY Amran and Susilawati. 2016. Utilization of black glutinous plant extract (Oryza sativa glutinosa) as indicator of acid-base. Ph. D. Dissertation. Riau University, Riau, Indonesia.

[13] A Astuti and B Wiyantoko. Extract Clitori Ternatea L. as an Indicator for acid-base titration testing. Indones. J. Chem. Anal. 2018; 1, 1-9.

[14] R Ginanjar, IWR Widarta and KA Nocianitri. Effect of solvent type and ratio of materials with solvents on the content of phenolic compounds and antioxidant activity of extracts of avocado seeds (Persea americana Mill.). J. Ilmu Teknol. Pangan. 2018; 7, 22-32.

[15] A Delazar, L Nahar, S Hamedeyazdan and SD Sarker. Microwave-assisted extraction in natural products isolation. Methods Mol Biol. 2012; 864, 89-115.

[16] S Amin and A Yuliana. Analysis and stability test of secang wood (Caesalpania sappan L.) using UV-visible and infrared spectrophotometers. J. Kesehat. Bakti Tunas Husada. 2016; 15, 56-63.

[17] A Tamzil, R Cindo and A Fresca. Effects of hexane and ethanol solvents, solvent volume, and extraction time on coffee oil extraction results. J. Chem. Eng. Sriwijaya Univ. 2009; 1, 1-7.

[18] G Nining, K Novitriani and U Mardiana. Determination of $\mathrm{pH}$ route of purple cabbage extract (brassica oleracea) as an indicator of acid base with variation of ethanol solvent concentration. $J$. Sci. Nurs. Sci. Health Anal. Pharm. 2016; 16, 94-100.

[19] P Melania, N Peni, L Carvallo and YD Ngapa. Anthocyanins and their Utilization. Cakra Kimia Indones. E-J. Appl. Chem. 2018; 6, 79-97. 